\title{
Reading Comprehension in Students with Autism Spectrum Disorder: The Role of Metacognitive Skills, Motivation, and Use of Strategies
}

\author{
Verónica Rebolledo Luna ${ }^{1}$, Antonio P. Gutierrez de Blume ${ }^{2 *}$ and Christian Soto ${ }^{3}$ \\ ${ }^{1}$ Universidad de Concepción \& Universidad Católica de la Santísima Concepción, Chile \\ ${ }^{2}$ Georgia Southern University, United States \\ ${ }^{3}$ Universidad de Concepción, Chile
}

Submission: October 27, 2021; Published: November 10, 2021

*Corresponding author: Antonio P Gutierrez de Blume, Department of Curriculum, Foundations, and Reading, Georgia Southern University, P.O. Box 8144, Statesboro, GA 30460-8144, Email:agutierrez@georgiasouthern.edu; USA.

\section{Abstract}

The purpose of the present exploratory study is to relate reading comprehension (ASD), metacomprehension skills, motivation for reading, and use of strategies among a group of students with autism spectrum disorder and their typically developing peers. More specifically, the aim was to determine which aspects can best explain performance in reading comprehension. Eighty-two students who were in the eighth grade to the fourth year of high school participated. They completed a standardized reading comprehension test, answered metacognitive measurement instruments, metacognitive monitoring, a questionnaire on motivation for reading, and a protocol for thinking aloud. According to the results, we conclude that metacognitive skills, motivation, and use of strategies significantly predicted performance in reading comprehension in students with ASD, and that there were some interesting differences between this group of students and their typical peers.

Keywords: Autism spectrum disorder; Reading comprehension; Metacomprehension skills; Motivation for reading; Comprehension strategies

\section{Introduction}

Autism Spectrum Disorder (ASD) is conceptualized as a disorder that is characterized by difficulties in social interaction, communication, and repetitive and restricted behaviors and interests [1]. Based on these characteristics, the literature in recent years has described that this population presents limitations in reading comprehension, which cannot be explained as difficulties in the basic processes of access to the written code or cognitive development [2].

Reading comprehension is one of the most important skills to develop during the learning process. It supports the basis for the acquisition of future learning, thereby influencing personal development. However, controlling understanding and learning is challenging. Research suggests that some people's ability to control or monitor their understanding is relatively poor $[3,4]$.

Therefore, for individuals with ASD, in addition to making descriptions that account for their reading comprehension skills, it is essential to inquire about how they face their limitations and what challenges discourse processing imposes on them. According to research in neurotypical populations, the findings are conclusive in terms of the weight of metacomprehension, holding that it affects reading performance [5-8].

The present study aims to determine what aspects of metacomprehension skills, reading motivation, and metacomprehension strategies can better explain the performance in reading comprehension in students with ASD who are enrolled between eighth grade and the fourth year of high school. It accomplishes this via a quantitative and exploratory approach.

\section{Materials and Methods}

Eighty-two Chilean youths participated, 41 of whom were diagnosed with ASD and 41 from the TIP group, who were typically developing peers. This comparison between the participants with ASD and their neurotypical peers will serve to define whether the 
metacomprehension difficulties observed in the population with ASD are unique or, on the contrary, are like those of their typically developing peers.

Reading comprehension was measured with Lectum, a standardized measure developed by Riffo et al. [6]. It evaluates the textual, pragmatic, and critical aspects involved in reading comprehension. Scores were transformed into percentiles, based on raw score performance.

Confidence in performance judgments were collected globally (before and after taking the test) and locally (item by item) by asking students to answer a question about their confidence in answering the item correctly. The responses were subsequently coded as 0 for incorrect and 1 for correct. Correct responses were summed for each participant and linearly transformed to percentiles.

The Meta-Understanding Inventory (MI), initially developed by Soto et al. [9], explores individuals' metacognitive dimensions. All elements of cognition knowledge were transformed into percentiles. The Motivations for Reading Questionnaire (MRQ), developed by Wigfield et al. [10], measures the main components of reading motivation in its theoretical components. Student scores were transformed into percentiles.

A think-aloud protocol was employed to infer the strategies used by the participants. Each participant's think-aloud was recorded in audio and video for subsequent transcription and coding of the presence of each strategy and the number of times these were repeated. These scores were also expressed as percentiles.

\section{Results}

Results demonstrated that both students with ASD and their typically developing peers showed expected performance in the comprehension test. However, there were statistically significant differences between both groups in the pragmatic dimension proposed by the Lectum test, in which the ASD group ( $M=25.12$, $S D=24.77)$ manifested a lower mean score compared to the typical group $(M=46.02, S D=25.35), F(1,80)=14.26, p<.001$, $\eta^{2}=.151$. This suggest that students with ASD have limitations in recognizing the characters, their social, cultural, and historical context, and the social function that the text presents according to their gender and, therefore, build the coherence of the text.

Regarding metacognitive monitoring, readers with ASD and typical readers exhibited better monitoring accuracy in the retrospective global judgments (after the task; ASD: $M=54.74, S D$ $=27.30$; typical: $M=51.49, S D=24.16$ ) than in the prospective judgments (before the task; ASD: $M=71.15, S D=24.83$; typical: $M$ $=69.02, S D=24.11), F(1,80)=69.70, p<.001, \eta^{2}=.466$; however, readers with ASD were less accurate in their metacognitive monitoring, although that difference was not statistically significant or meaningful, $p=.78, \eta^{2}=.001$. In addition, a series of stepwise ordinary least squares regressions showed similar predictive patterns for both groups. More specifically, reading comprehension performance was only predicted by the raw frequencies of cell a and cell c of local monitoring accuracy (see Schraw et al., [11], for a comprehensive explanation of the $2 \mathrm{x}$ 2 performance judgment-actual performance array). For the typical group, the omnibus model was practically and statistically significant, $F(4,36)=62.58, p<.001, \mathrm{R}^{2}$ adjusted $=.860$; the same was the case for the ASD group, $F(4,36)=34.60, p<.001, \mathrm{R}_{\text {adjusted }}^{2}=$ .771. Cell a (correct performance judged to be correct) positively predicted reading comprehension (ASD group: $b=4.57\left[\mathrm{CI}_{95 \%}=\right.$ 3.28, 5.86]; $\beta=.97, p<.001$; typical group: $b=4.89\left[\mathrm{CI}_{95 \%}=3.79\right.$, 5.99]; $\beta=.76, p<.001$ ) whereas cell c (correct performance judged to be incorrect, also known as under confidence or an illusion of not knowing) negatively predicted (ASD group: $b=2.84\left[\mathrm{CI}_{95 \%}=\right.$ $.29,5.41] ; \beta=.22, p=.03$; typical group: $b=5.00\left[\mathrm{CI}_{95 \%}=2.64\right.$, 7.36]; $\beta=.33, p<.001$ ) reading comprehension.

Regarding metacognitive knowledge, planning $(b=.60$ $\left[\mathrm{CI}_{95 \%}=.27, .94\right] ; \beta=.50, p=.001$ ) positively predicted reading comprehension for the ASD group, $F(1,39)=13.26, p=.001$, $\mathrm{R}_{\text {adjusted }}^{2}=.235$, whereas reading process evaluation $\left(b=.51\left[\mathrm{CI}_{95 \%}\right.\right.$ $=.16, .86] ; \beta=.43, p=.005), F(1,39)=8.70, p=.005, \mathrm{R}^{2}$ adjusted $=$ .161 , positively predicted reading comprehension for the typical group. In reading motivation, reading efficacy $\left(b=.63\left[\mathrm{CI}_{95 \%}=.22\right.\right.$, $1.05] ; \beta=.44, p=.004), F(1,39)=9.42, p=.004, \mathrm{R}^{2}$ adjusted $=.174$, positively predicted reading comprehension for the ASD group, meaning that this group has beliefs about reading adequately. For the typical group, self-efficacy $\left(b=.61\left[\mathrm{CI}_{95 \%}=.32, .91\right] ; \beta=.56, \mathrm{p}<\right.$ $.001), F(1,39)=17.40, p<.001, \mathrm{R}_{\text {adjusted }}^{2}=.291$, positively predicted reading comprehension, meaning that typical readers strive for satisfaction for mastering complex ideas in a text and, like the ASD group, present beliefs for reading adequately.

With respect to strategies, for the ASD group, bridging inferences $\left(b=2.71\left[\mathrm{CI}_{95 \%}=.32,5.09\right] ; \beta=.32, p=.027\right)$, elaborative inferences $\left(b=1.12\left[\mathrm{CI}_{95 \%}=.15,2.09\right] ; \beta=.32, p=\right.$ $.025)$, and paraphrasing $\left(b=.27\left[\mathrm{CI}_{95 \%}=.02, .52\right] ; \beta=.28, p=.037\right)$ positively predicted reading comprehension, $F(3,37)=7.27, p=$ $.001, \mathrm{R}^{2}$ adjusted $=.320$. For the typical group, the total score in the use of all strategies $\left(b=2.88\left[\mathrm{CI}_{95 \%}=1.98,3.78\right] ; \beta=.66, p<.001\right)$ and elaborative inferences $\left(b=.82\left[\mathrm{CI}_{95 \%}=.25,1.40\right] ; \beta=.29, p\right.$ $=.006)$ positively predicted reading comprehension, $F(2,38)=$ $45.34, p<.001, \mathrm{R}_{\text {adjusted }}^{2}=.689$.

\section{Discussion and Conclusion}

These findings allow us to conclude that people with ASD achieve normal performance in the reading comprehension test; however, in the pragmatic aspects of reading comprehension, as measured by Lectum, they evince lower performance. In addition, the results reveal that metacognitive elements, motivation for reading, and the use of comprehension strategies significantly predicted reading performance in this group of students; nevertheless, not all the variables present a significant effect. In this sense, there is a greater tendency to use a type of low-level strategies, which help to maintain local coherence (paraphrasing, 
bridging inference). There is plausibly a bias in the reading of students with ADS around the flexibility factor, which decreases their ability to process certain types of information (affecting the integration process). This becomes more evident in the processing of pragmatic situations where, despite the strategies used, they tend to lose control in reading efficiency. This is congruent with extant research $[7,12]$, and it underscores the need to tailor educational interventions to exceptional students with learning disabilities, such as ASD.

\section{Acknowledgment}

a) This work was funded by the National Agency for Research and Development (ANID) / Scholarship Program / DOCTORADO BECAS CHILE/2020.

Agencia Nacional de Investigación y Desarrollo (ANID) with grant number FONDEF ID20110290.

\section{References}

1. American Psychiatric Association (2013) Diagnostic and statistical manual of mental disorders. (5th edn), (DSM-5). American Psychiatric Publishing.

2. Saldaña D (2008) Teoría de la mente y lectura en las personas con trastorno del espectro autista: hipótesis para una relación compleja. Revista de Logopedia, Foniatría y Audiología 28(2): 117-125.

3. McNamara D, Ozuru Y, Best R, O Reilly T (2007) The 4 - pronged comprehension strategy framework. In D. S. McNamara (Ed.), Reading comprehension strategies: Theories, interventions, and technologies, pp. 465-496.

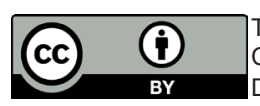

This work is licensed under Creative Commons Attribution 4.0 License DOI: 10.19080/GJIDD.2021.09.555758
4. Duke NK, Pearson PD (2002) Effective Practices for Developing Reading Comprehension. EEUU: International Reading Association.

5. Guthrie JT, Klauda SL, Ho AN (2013) Modeling the relationships among reading instruction, motivation, engagement, and achievement for adolescents. Reading Research Quarterly 48(1): 9-26.

6. Riffo B, Véliz M, Castro G, Reyes F, Figueroa B, Salazar O, Herrera MO (2011) LECTUM. Prueba de comprensión lectora. Conicyt, Proyecto Fondef D08i1179.

7. Soto C, Gutierrez de Blume AP, Rodriguez MF, Asún R, Figueroa M, Serrano M (2019) Impact of bridging strategy and feeling of knowing judgments on reading comprehension using COMPRENDE: An educational technology. Tech Trends 63(5): 570-582.

8. Wolters C, Denton C, York M, Francis D (2014) Adolescents' motivation for reading: Group differences and relation to standardized achievement. Reading \& Writing 27(3): 503-533.

9. Soto C, Rodriguez Poblete MF, Gutierrez de Blume AP (2018) Exploring the meta-comprehension abilities of students with intellectual disabilities. International Journal of Special Education 33(2): 233-247.

10. Wigfield A, Guthrie JT, Tonks S, Perencevich K (2004) Children's motivation for reading: Domain-specificity and instructional influences. The Journal of Educational Research 97(6): 299-310.

11. Schraw G, Kuch F, Gutierrez AP, Richmond A (2014) Exploring a threelevel model of calibration accuracy. Journal of Educational Psychology 106: 1192-1202.

12. Soto C, Gutierrez de Blume A, Asun R, Jacovina M, Vásquez C (2018) A deeper understanding of metacomprehension in reading: Development of a new multidimensional tool. Frontline Learning Research 6(1): 3153.

\section{Your next submission with Juniper Publishers will reach you the below assets}

- Quality Editorial service

- Swift Peer Review

- Reprints availability

- E-prints Service

- Manuscript Podcast for convenient understanding

- Global attainment for your research

- Manuscript accessibility in different formats

( Pdf, E-pub, Full Text, Audio)

- Unceasing customer service

Track the below URL for one-step submission https://juniperpublishers.com/online-submission.php 